\title{
Factors Influencing Girl's Performance in Physics in National Schools in Kiambu and Nairobi Counties of Kenya
}

\author{
J. Akweya, N. Twoli, G. Waweru \\ Department of Educational Communication Technology, Kenyatta University, Nairobi, Kenya
}

Email address:

jakweyas@yahoo.com (J. Akweya),nicholastwoli@yahoo.com (N. Twoli), giwawa06@yahoo.com (G. Waweru)

To cite this article:

J. Akweya, N. Twoli, G. Waweru. Factors Influencing Girl's Performance in Physics in National Schools in Kiambu and Nairobi Counties of Kenya. International Journal of Secondary Education. Vol. 3, No. 4, 2015, pp. 26-31. doi: 10.11648/j.ijsedu.20150304.11

\begin{abstract}
This study was designed to investigate factors that influence girls' enrolment and performance in physics in five (28\%) traditional national schools in Kenya. Meaningful learning of physics is the hallmark of a technologically competent workforce in science, technology and engineering. However, there is a lower performance index and enrolment of girls opting to study physics at Kenya Certificate of Secondary Education (KCSE). Specifically, the factors of attitudes of students, learners' ability and teacher characteristics were found to affect enrolment and performance of girls in physics. Three theories that influence the understanding of the issues in this study include Bloom's Theory of Affect, Bruner's Theory of Constructivism and Kneller's Progressive Theory. Despite intervention measures by the Ministry of Education to alleviate girls' polarization in enrolment and performance in physics, the Ministry of Education Science and Technology (MOEST), 2006 module report upholds that there are negative influences in the teaching and learning of science. A wide range of literature review on girls' enrolment and performance in physics nationally and in sub county schools showed low enrolment and poor performance at KCSE. However, no research was evident on factors that influence girls' performance in physics in Kenya national schools. The study used a survey design among five national schools in Nairobi and Kiambu counties; form two class was chosen as the target population as well as teachers of science and mathematics in the five schools. Purposive and simple random sampling was used in the study. A random sample of two hundred and twenty eight form two students was selected from the five schools. From each school a sample of forty five students was selected using a simple random sampling method. Questionnaires were used to collect data for both teacher and student factors. In addition, an Achievement Test was used to isolate areas of misconceptions that account for poor performance of girls compared to boys. The data was analysed using both descriptive and inferential statistics. Statistical Package for Social Sciences (SPSS) was used in data analysis. Means, frequency distributions and percentages, histograms, and pie charts were determined. Likert Scale was used to measure attitudes affecting performance of physics among all the targeted girls' schools and the teachers. The study showed students' attitude, learner's ability and teacher characteristics, affected girls' enrolment and performance in physics in national schools. The girls had better positive attitudes and performance in learner abilities in physics than the boys. The results also showed that teachers of physics in girls' national schools are effective and efficient in instructional designs. The findings of this study may be used to foster positive attitudes towards physics. The methods of physics instruction among girls may also be impacted by constructivism approaches as the results show strong preference to physics practical work.
\end{abstract}

Keywords: Secondary Education, Girl Child Performance, Physics, Science Education

\section{Introduction}

Physics education is an important part of the foundation for many occupations (VanGorden and Slater, 1998) and consequently, the issue of enrolment and performance of girls in physics has been a subject of discussion and research globally (Farmer, 1993). The United Kingdom (UK), Dainton report of 1968 established that the number of boys studying physical science subjects beyond compulsory period far outweighed the number of girls. Likewise Kenya National Examinations Council (KNEC) reports of 2004 to 2010 attest this similarity as shown in Figure 1.1. 


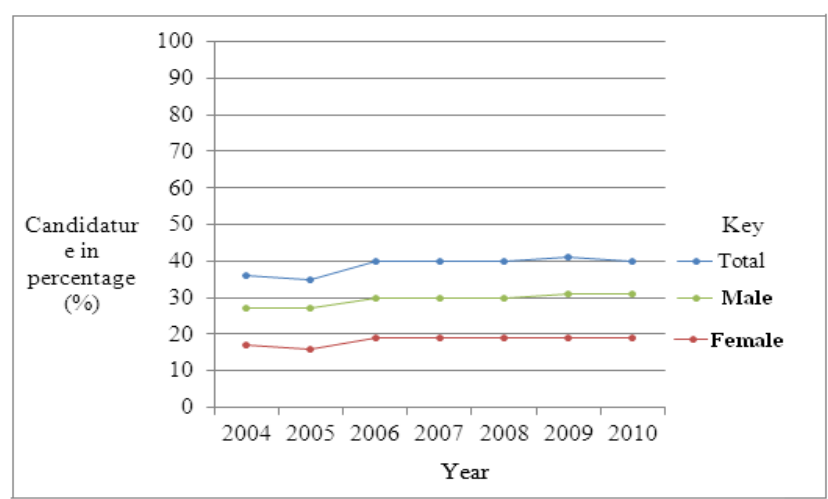

Source: KNEC, 2004 - 2010 Reports.

Figure 1.1. National KCSE candidature in physics (2004-2010).

Figure 1.1 shows KNEC physics enrolment of female and male candidates in national examinations during 2004 - 2010. The trend of females being outnumbered by males is evident, almost in the ratio $1: 2$. This is in spite of an overall trend of KCSE physics enrollment being below forty one percent (41\%) nationally.

The current high school curriculum in Kenya puts emphasis on science subjects and yet students' performance in the science subjects in national examinations has been consistently poor over the years (Madera, 2001). Despite equal education opportunities, there is growing evidence since 1990's that boys have continued to perform better than girls in physics (Elimu, 2007). However, there is no evidence to suggest that girls and boys have any significant inherent differences in ability (Bennett, 2003). A review of literature by Zhu (2007) shows that Self-Efficacy (SE) is a successful predictor of students' course-taking although many other factors which are contextual variables have been reported to have influence on Physics Self-Efficacy (PSE).

\section{Literature Review}

It is increasingly important that the nature and ways of science be understood and how actions of society affect living things (Enger and Ross 2000). Studies done by O'Brien (2002), show that boys are more likely to take all the three core science courses (biology, chemistry, and physics) and enroll in advanced placement physics approximately three times as often as do the girls.

An earlier study by Duckworth and Ormerod, (1975) found physics to be preferred and more widely chosen by boys than girls. However, students' enrolment in physics is inhibited by conflicts with other courses, extracurricular activities and fear of failure (Crawley and Black, 1992). This trend of low enrolment in physics is also observed in Kenya following KNEC 2006 and 2007 Reports.

Science is perceived as masculine from the way it is presented (Bennett, 2003).

Kelly (1985) identified four senses in which science could be considered to be masculine. First, the majority of those who choose to study it are male, so that it is seen as a predominantly male area of academic activity. Second, it is mode of instruction suits more the interest and motivation of boys. Third, behaviours in science classes are such that boys and girls act out characteristic gender roles. Finally Kelly (1985) suggested that because it has been socially constructed in a parochial male-dominated society, science is itself inherently masculine. However, this suggestions do not rule that female are incompetent in studying science for milestone scientific works have been achieved by females like Madame Mary Curie and Florence Bacon (Tillery, 2007) in the history of science.

The experimental nature of science fosters teamwork and manipulative skills of objects as well as promoting observational, deductive and evaluative skills (Wan and Van, 2006). Science derives its power and authority from its empirical method; a method that comprises a sure and reliable inference from observation and experiment. This authority is from the senses and experiences from which scientific knowledge is constructed (Stanesby, 1985). It is the nature of science therefore to look for more new knowledge, through two processes referred to as deductive and inductive reasoning (MOEST Science Module, 2001). These skills sit well within the KCSE physics course and are essential in the learning and teaching of physics, especially in field trips, practical and project work, (KIE Secondary Syllabus, 2002). Teaching to understand science follows Bacon's view of understanding nature from consulting nature and not the writings of Aristotle (Stanesby, 1985).

Scientific methods and values include seeking to answer questions using some kind of evidence, recognizing the importance of rechecking data, and understanding that scientific knowledge and theories change over time as more information is gathered (Rezba, 1999). Science contributes its unique skills, with its emphasis on hypothesizing, manipulating the physical world and reasoning from data (Padilla, 1990).

Scientific investigation in Figure 2.1 includes proposing an explanation for the observation made, use of explanations to make predictions, testing of predictions by doing an experiment by making multiple observations, modification of explanation if need be, and drawing conclusion(s).

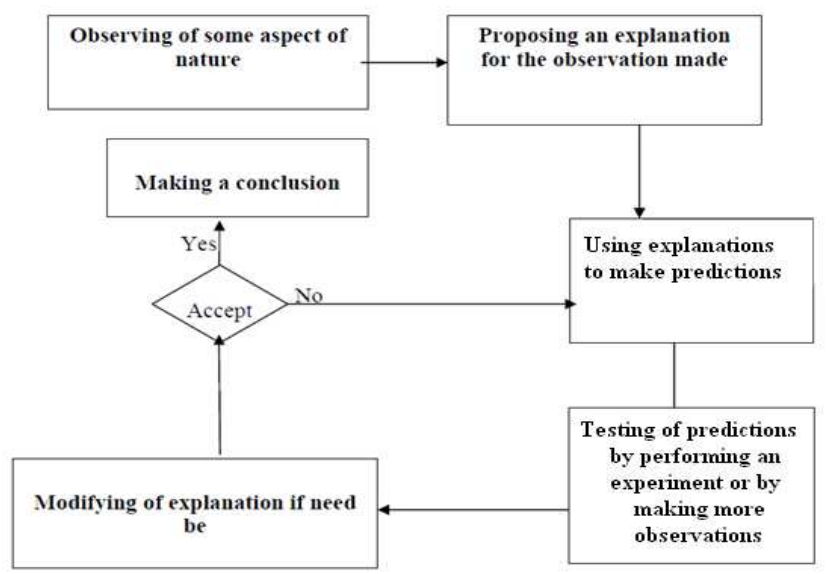

Figure 2.1. Steps in scientific investigation Source: Developed by Akweya, J. S. (2012). 


\section{Methodology}

\subsection{Research Design}

The Research was designed and developed as illustrated below.

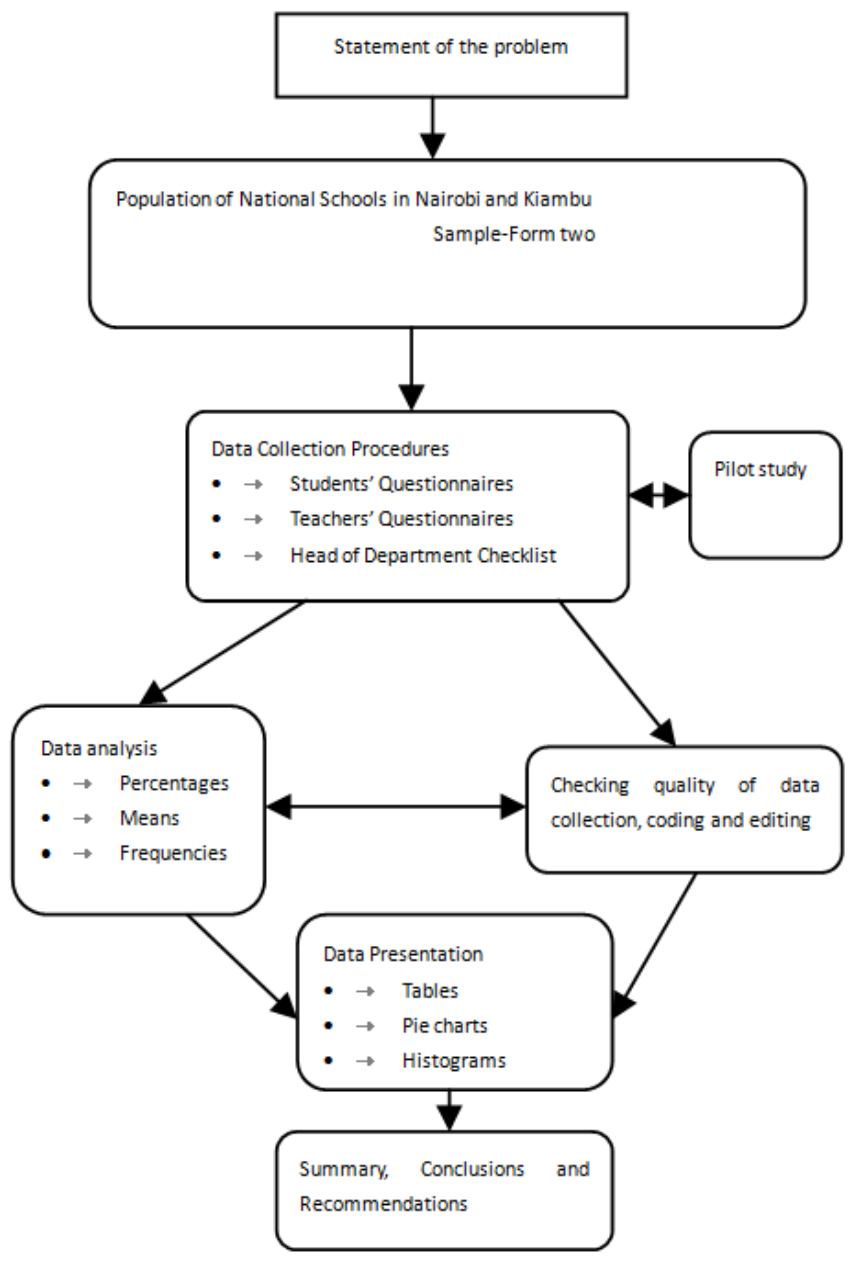

Figure 3.1. Research Design.

Four instruments (Physics Student Questionnaire (PSQ), Teacher Questionnaire (TQ), Head of Department Checklist (HDC) and Learner Achievement Test (LAT) were used during the study.

\subsection{Results and Interpretation}

The government of Kenya has formulated policies to industrialize the country by 2030 . However, low enrolment and performance index of girls opting to study physics can be a setback. This deficit can have serious implications for the career options available to women given that an average of just 8 per cent girls enroll in the physics course in high schools in Kenya (KNEC Report, 2007). Thus, the persistence of less girls opting to study physics is worrying and calls for further investigation, especially when it comes to the cream of the girls in the national schools. This study was set to investigate factors affecting girls' enrolment and performance of physics in Kenyan National Schools. The main objective of the study was to investigate the factors that influence girls' enrolment and performance in physics in national schools in Kenya. The study was set to find out:

- the attitudes of girls as compared to the attitudes of boys towards the learning of physics,

- the effect of learner abilities of girls' performance in physics,

- teachers' characteristics that influence girls' enrolment

- characteristics that influence girls' performance in physics.

The following were the main findings of the study:

a) The attitude of girls towards studying physics in national schools in Kenya is better (4.06) and was slightly higher than that of the boys (4.00). This is the main reason why girls opt to enroll to study physics at KCSE. The attitude is influenced by the life around the girls, career related factors such as studying engineering and technological courses at tertiary levels.

b) Girls in national schools are good in physics when it comes to developing and applying key abilities like mathematical, spatial and concept development.

c) Instructional modes that benefitted girls most in national schools were remedial teaching, present in seventy per cent (70\%) measure, which is used to clarify some difficult concepts, and team teaching in fifty per cent $(50 \%)$ measure.

d) The attitude scale shows that teachers of physics in the national girls' schools are positive when it comes to commitment of instruction of physics. Teachers go a long way to ensure that girls like and understand the study of physics.

e) The workload of physics teachers in national girls' schools is modest. This allows teachers to invest more time to guide girls in physics content.

\section{Conclusion}

The investigation in this study established the relationship between instruction of physics among girls versus their enrolment and performance in reference to Kneller's progressive theory, Brunner's constructivism theory and Bloom's instructional theory. Upholding Kneller's progressive theory girls are influenced to enroll for physics so long as Brunner's constructive theory and Bloom's instructional theory are used during physics instruction. Applying Brunner's constructive theory and Bloom's instructional theory in physics instruction guarantees good performance in physics.

The results show that enrolment and performance of girls in physics in national schools in Kenya are influenced by attitude, learner abilities and teacher characteristics. The research showed a positive attitude towards physics among girls in national schools. However, low enrolment in physics at KCSE is affected by the less negative attitude and low performance of girls. Girls can be 'delicate' and a 'small' attribute can lift or derail a girl from studying physics. That is why teachers of physics have to go an extra mile in preparation, instruction and assessment, in school physics. 


\section{Acknowledgements}

More Appreciation for professional advice and positive criticism goes to the tutors of the Educational Communication and Technology Department. This was valuable and useful in the development of the entire thesis.

Most gratitude is owed to Akweya's family, college mates at Kenyatta University and the management of Alliance High School for their cooperation during the course of this research to all those teachers and students who were ever willing to respond to research instruments during data collection.

\section{References}

[1] Alters, B. J. (1995) Counseling Physics Students: A Research Basis. The Physics Teacher, 33, Pp.413- 415.

[2] Bell, J. (1987). Doing Your Research Project. A Guide for First-Time Research in Education and Social Science, Milton Keynes, U.S.A, Philadelphia Open University Press.

[3] Bennett, J. (2003). Teaching and Learning Science. London, U.K. Continuum.

[4] Bloom B. S. (1956). Taxonomy of Educational Objectives. Handbook I: The Cognitive Domain. New York, U.S.A, David McKay Co Inc.

[5] Bock, R.D. and Kolakowski, D. (1973). 'Further evidence of sex-linked major gene influence on human spatial visualizing ability'. American Journal of Human Genetics, vol. 25, pp. $1-14$.

[6] Brinkmann, E. (1966) Programmed Instruction as a Technique for Improving Spatial Visualization. Journal of Applied Psychology, 50, pp 179-184.

[7] Britner, S.L. and Pajares, F. (2001) Self-efficacy beliefs, motivation, race and gender in middle school science. Journal of Women and Minorities in Science and Engineering, 7, pp. 271-285

[8] Broverman, D.M., Klaiber, E.L., Kobayashi, Y. Vogel, W. (1968). 'Roles of activation and inhibition in sex differences in cognitive abilities'. Psychological Review, vol. 75, pp 25-30.

[9] Burton, L. (2007). Concepts, Hypotheses, and Theoretical Frameworks. John Hopkins University. www.ocw.jhsph.edu/hsre/PDFs/HSRE.lect3- burton pdf.

[10] Cherry, G. (2004). An Overview of Jerome Brunner His Theory of Constructivism. In Partial Fulfillment of the Requirements for ECI 761. Richard Overbaugh. March 18th.

[11] Chiriswa, P. (2002).An Investigation into the Probable Factors Responsible for Poor Performance in Kenya Certificate of Secondary Education (KCSE) In Vihiga District Of Western Province, Kenya. Unpublished MEd Thesis. Kenyatta University. Kenya

[12] Comber, L.C. and Keeves, J.P. (1973). Science Education in Nineteen Countries. An Empirical Study. New York, U.S.A, A Halsted Press Book.

[13] Constructivism Theory. (2004). http://tip.psychology.org/ bruner.html
[14] Crawley, F.E. and Black, C. (1992). 'Causal Modeling of Secondary Science Students' Intentions to Enroll in Physics'. Journal of Research in Science Teaching. 29 (6) pp. 585-599.

[15] Dainton (1968). Dainton report HC Deb 14 March, 1968. Vol. $760 \mathrm{cc} 1601-2$

[16] Danielson, C. (2007) Enhancing professional practice. A framework for taeaching. 2nd edition. Aleaxandaria, VA. Association for Supervision and Curriculum Development.

[17] Delialioglu, O. and Askar, P. (1999). Contribution of Students' Mathematical Skills and Spatial Ability to Achievement in Secondary Schools Physics. Journal of Education.16-17: pp.34 $-39$

[18] Duckworth, D. and Ormerod, M.B. (1975). Pupils' Attitude to Science. New Jersey, U.S.A. Humanities Press Atlantic Highlands.

[19] Efumbi, M.D.W.(2002).An Investigation Into Factors Associated With Low Achievement Of Students In Chemistry Subject In Busia At Kenya Certificate Of Secondary Education Level. Unpublished MEd Thesis. Kenyatta University. Kenya.

[20] Elimu News. (2007). A Newsletter of the Ministry of Education. Issue No. 1.

[21] Elliot, W.E. (2000). Prospects: the quarterly review of comparative education. Paris, Vol 30 no. 3, UNESCO.

[22] Eisner, E.W. (2000). Benjamin Bloom 1913-99. A Paper by Prof. Elliot

[23] W. Eisner UNESCO Bureau of Education. Enger, E. D and Ross, F. C. (2000). Concepts in Biology. Boston, USA, The McGraw-Hill Companies.

[24] Farmer, M.H.(1993). Preparedness Assessment of First Year Physical Science Students in a Two - Year College. Journal of College Science Teaching. Pp. $346-350$.

[25] Fennema, E. (1976). Influences of Selected Cognitive, Affective and Educational Variables in Sex-related Differences in Mathematics. Department of Curriculum and Instruction, Madison, U.S.A, University of Wisconsin.

[26] Gallenstein, N.L. (2004). Creative Discover Through Classification. Teaching Children Mathematics. Vol 11. pp.103-4.

[27] Gatara, T. H. (2010). Introduction to Research Methodology. Nairobi, Kenya. The Olive Marketing and Publishing Company

[28] Glennon, V.J. and Callahan, L. G. (1968). A Guide to Current Research: Elementary School Mathematics. Association for Supervision and Curriculum Development. Washington D.C. U.S.A

[29] Griffith, W. T., (1985) Factors Affecting Perfomance in Introductory Physics Courses. American Journal of Physics, 53 (9), 839-842

[30] Grote, M.(1995). Sure You Care, But Do Students Know It? The Physics Teacher, 33(Feb. 1995), pp 92-95

[31] Grote, M (1994). Recruiting Students for High-School Physics Classes. The Physics Teacher, 32(September 1994), pp 350-351.

[32] Hakim, T.(2007). High School Physics Enrolment Hits Record High. Science Daily. January 11th 
[33] Harding, J. (1986). Switched Off: The Science Education of Girls. York, U.K. Longman.

[34] Hart, G. and Cottle, P.(1993) Academic Backgrounds and Achievement in College Physics. The Physics Teacher pp. 470 $-475$

[35] Hartlage, L.C. (1970). 'Sex-linked inheritance of spatial ability'. Perceptual and Motor Skills, vol. 31, p. 610.

[36] Holliday, W. (1975) "The effects of verbal and adjunct pictorial-verbal information in science instruction.” Journal of research in science teaching, 12 (8) pp 892-901

[37] Hughes, A.G. and Hughes, E.H. (1959). Learning and Teaching. An Introduction to Psychology and Education. London, Longmans.

[38] Hyde, J. (1981). 'How large are cognitive gender differences?'American Psychologist. 36 (8) pp. 892-901

[39] Kahn, S.B. and Weiss, J. (1973). The Teaching of Affective Responses in Travers, R.M.W. (ed) Second Hand Book of Research on Teaching. Chicago, USA. Rand McNally.

[40] Juma, C. and Cheong, L. Y. (2005). UN Millennium Project. Task Force on Science, Technology, and Innovation. Innovation: applying knowledge in development. Achieving the Millennium Development Goals. London. Earthscan.

[41] Kahle, J.B., and Meece, J. (1994) Research on gender issues in the classroom. In D. Gabel (Ed.), Handbook of research on science teaching and learning. New York: Macmillan.

[42] Kelly, A. (1985). 'The construction of masculine science'.

[43] British Journal of Sociology of Education, 6(2), 133-153.

[44] Kenya Vision 2030. (2007) A Globally Competitive and Prosperous Kenya. Nairobi, Kenya. Government Printer.

[45] KIE. Secondary Education Syllabus (2002). Mathematics, Chemistry, Physics, Biology and Agriculture. Volume Two. Nairobi, Kenya. Kenya Literature Bureau.

[46] KNEC. (2010). Report on Monitoring learner achievement for class 3 in numeracy and literacy. TEACHING FOCUS POSTER. Nairobi, Kenya. Kalzmat Security Print Ltd.

[47] KNEC. (2006). The Year 2005 KCSE Examination Report Kenya National Examinations Council 2006. Nairobi. Printed by KNEC

[48] KNEC. (2007). The year 2006 KCSE examination Report Kenya National Examinations Council. Nairobi, Kenya. Printed by KNEC

[49] KNEC. (2011). Confidential Marking Regulations. Kenya National Examination Council. Nairobi, Kenya. Printed by KNEC

[50] KNEC. (2010). KCSE Regulations and Syllabuses 2010- 2011. Kenya National Examination Council. Nairobi, Kenya. Printed by KNEC

[51] Kneller, G.F. (1971). Introduction to the Philosophy of Education. New York, John Wiley and Sons, Inc.

[52] Kozherrnikov, M., Motes, M., and Hergarty, M. (2007). Spatial visualization in physics problem solving. Cognitive Science, 31, pp519-579
[53] Krathwhol, D. R. and Anderson L.W. (2001). A Taxonomy for Learning Teaching and Assessing. A Revision of Bloom's Taxonomy of Educational Objectives. Boston, USA, Allyne and Bacon.

[54] Leslie, L. L., McClure, G. T. and Oaxaca, R. L. (1998) Women and minorities in science and engineering: A life sequence analysis. The journal of higher education, 69, (3), pp. 239-276

[55] Lord, T.R. (1985). Enhancing the visuo-spatual aptitude of students.Journal of research in science teaching, 22(5), pp. 395-405.

[56] Lyons, T. (2005). The Puzzle of Falling Enrolments in Physics and Chemistry Courses: Putting Some Pieces Together. Research in Science Education. DOI: 10, 1007/s11165-005-9008-z

[57] Maccoby, E. and Jacklin, C. (1975). The Psychology of Sex Differences. London, Wiley.

[58] Madera, S.N.(2001) Teaching and Learning High School Physics Through Analogies :A Case Study of Kenyan Classrooms. Unpublished Doctor of Education Thesis Department of curriculum, Teaching and Learning. Ontario Institute of studies and Education of the University of Toronto

[59] McFie, J. (1973) Intellectual Imbalance: A Perceptual Hypothesis. British Journal of Socal Clinical Psychology, 12. pp 433-434.

[60] Mayer, R.E. (2003). Learning and Instruction. Pearson Education. Inc. Upper Saddle River pp. 287-88

[61] MOE. (2007). A Newsletter of the Ministry of Education. Elimu News. Issue No. 1. Nairobi, Kenya.

[62] MOEST. (2001). Science Module. Teaching and Learning Science in the Primary Classroom. SPRED. School based Teacher Development (SbTD). Nairobi, Kenya.

[63] Nueschatz, M. and Covalt, M. (1988). Physics in the High Schools. American Institute of Physics. New York, U.S.A.

[64] Ong, W., (1981) Fighting for life. Ithaca, U.S.A. Cornell University Press

[65] O'Brien, S.B. (2002). Where the girls aren't: High school girls and advanced placement physics enrolment. Dissertation and Theses Paper AAI3043392. Boston College, U.S.A.

[66] Padilla, M.J. (1990). 'Research Matters - to the Science Teacher'. No. 9004 University of Georgia, Athens, GA

[67] Pallrand, G. J. and Seeber, F. (1984), 'Spatial ability and achievement in introductory physics'. Journal of Research in Science Teaching, vol. 21: issue 5 pp. 507-516.

[68] Palvio, A. (1970) On the further significance of image "Phsychological bulletin" 73 (3) 385-392.

[69] Peltzer, A. (1988). The intellectual factors believed by physicists to be most important to physics students." Journal of research in science teaching, 25(9) pp 721-731

[70] Ramsey, G .A. and Howe, R.W. (1969 a). An analysis of Research on Instructional Procedures in Secondary School Science, Part I- Outcomes of Instruction. Science Teacher. 36, 3, pp 62-81 
[71] Rezba, R. J. (1999).Teaching and Learning The Basic Science Skills: Video tape Series. Office of Elementary and Middle School Instructional Services, Virginia Department of Education, P.O. Box 2120, Richmond, VA 23218-2120. Call media office for copies of videotapes at 804-225-2980.

[72] Robinson, M. (1991). Raise Your Enrolment. The Science Teacher, 58(Feb. 1991) pp 24-27.

[73] Sells, L. W. (1973). High school mathematics as the critical fitter in the job market. Developing opportunities for minorities in Graduate Education, pp. 47-59. Proceedings of the Conference on Minority Graduate Education at the University of California, Berkeley, U.S.A.

[74] Serbin, A.L. (1972). Sex Differences in the Pre school Classroom: Patterns of Social Reinforcement. Doctorial Dissertation. State University of New York. NY.

[75] Shaw, R. (1995). Principles of teaching. An Independent Study Textbook. Texas, U.S.A. ICI University Press.

[76] Siemankowski, F. and Macknight, F. (1971). Spatial Cognition: Success prognosticator in college science courses. Journal of college science teaching 59. Pp1-56

[77] Shaycoft, M.F., Dailey, J.T., Orr, D.B., Neyman, C.A., Jr., Sherman, S.E. (1963). The identification Development and Utilization of Human Talents: Studies of Complete Age Group -15. Pittsburgh, PA: University of Pittsburgh, Project Talent Office.

[78] Sherman, J. (1977). Sex-related differences in mathematics achievement, spatial visualization and affective factors. American Educational Research Journal, Winter, vol. 14, no. 1, pp 51-71.

[79] Sobolewski, S.J (1993). A latent variable path analysis model of secondary physics enrolment in New York State. A presentation and discussion at the annual meeting of national association of research in science teaching. Atlanta. G.A. April 17.

[80] Sorby, S.A. (2001). A course in spatial visualization and its impact on the retention of female engineering students. Journal of Women and Minorities in Science and Engineering, 7, Pp153-172.
[81] Stafford, R. E.(1961). Sex differences in spatial visualization as evidence of sex-linked inheritance. Perceptual and Motor Skills. Vol 13, p148.

[82] Stanesby, D. M. (1985). Science, Reason and Religion. London and New York, Routledge, Croom Helm Ltd.

[83] Suydam, M.N. and Riedesel, C.A. (1969) Interpretive Study of Research and Development in Elementary School Mathematics. Vol. 1. Introduction and Summary: What Research says, Final Report, Project no. 8- 0586. Department of Health, Education and Welfare.

[84] Tillery, W.B. (2007). Physics Customized Physical Science. Boston. U.S.A. Custom Publishing

[85] Tsuma, O.G.K. (1998).Tsuma. Science Education in the African Context. Nairobi, Kenya. Jomo Kenyatta Foundation.

[86] Twoli, N.W. (1986). Sex Differences in Science Achievement Among Secondary School Students in Kenya. Unpublished $\mathrm{PhD}$ Thesis. Flinders University. Australia.

[87] VanGorden, T., and Slater, T.S., (1998). Factors Influencing Kansas High School Physics Enrolment. Kansas Science Teacher, 139(1), Pp 25-28.

[88] Wanjama, L.N, Muraya P.N, and Gichaga S.N. (2006). Life Skills. A Handbook for Parents and Teachers. Nairobi, Kenya. The Jomo Kenyatta Foundation.

[89] Wan, N. and Van, T.N. (2006). 'International Education Journal'. 7(1), 36-50. Shannon Research Press.

[90] Wiggins, G. (2009). On Excellence in Teaching. Bloomington, Indiana, U.S.A. Solution Tree Press.

[91] Whyte, J. (1996). Girls into Science and Technology. London, U.K. Routledge.

[92] Wittig, M.A. (1976). Sex differences in intellectual functioning: how much difference do genes make? Sex Roles. vol. 2, pp. 63-74.

[93] Zhu, Z. (2007). Learning content, physics self - efficacy, and female students' physics-taking. International Education Journal, 8(2), 204-212. Shannon Research Press. http://iej.com.au 